\title{
The current situation and prospects of fisheries certification and ecolabelling
}

\section{Introduction}

The world's per capita fish consumption has doubled in the last few decades, yet wild capture fishery landings have peaked with limitations for further expansion (FAO, 2014). Despite national and regional successes in fisheries management and governance, 30\% of global fish stocks remain overexploited (FAO, 2014). To maintain wild fish supplies to support a growing population, both governments and intergovernmental management organizations are faced with the challenge of rebuilding depleted fish stocks and maintaining healthy stocks at or above optimal sustainable levels.

A suite of management actions and institutional reforms can support the state in achieving these goals. Depending on the specific context of a given fishery, governments may choose to implement catch controls and gear modifications, and/or apply rights-based and/or community-based management (Worm et al., 2009; Gutierrez et al., 2011). Moving beyond the State, fisheries certification and ecolabelling has also emerged as an approach for harnessing market forces to create an incentive, through price premiums for example, for sustainable, well-managed fisheries. There are currently around 30 certification programs available to fisheries (Parkes et al., 2010), two of the most dominant of which are the Marine Stewardship Council (MSC) and the Friend of the Sea (FoS). Recently, social certification has also been introduced through the USA FairTrade standard (Bailey et al., 2016). Certification programs are also being increasingly developed by national organizations seeking to adapt fisheries standards to local contexts and to address domestic or regional demands (Kvalvik et al., 2014; Perez-Ramirez, in 2016). In addition, both national and global awareness campaigns and so called recommendation lists or 'wallet cards' (e.g., Monterey Bay Aquarium Seafood Watch) have proliferated, aiming to influence consumer choices and therefore market demand for sustainability as a core product attribute.

Seafood certification programs set a prescriptive standard to verify fisheries sustainability and that State or State-recognized fisheries regulations are effective and well enforced. As defined by FAO's Guidelines for the Ecolabelling of Fish and Fishery Products (FAO, 2005), these programs must be voluntary, incorporate reliable, independent auditing and verification procedures, and be non-discriminatory among other requirements. Certification programs identify a fishery (often defined as the combination of fish stock and fleet), rather than a species, to be the primary unit of assessment. In doing so, recognition is given to the variation of fishing practices across fleets, and acknowledgement to those that adopt environmentally sound and responsible actions. A successful assessment of a fishery is then communicated to consumers through an ecolabel on a product. Consumer preference for these ecolabelled products may enable to fishers to maintain their position in a given market, or gain access to new and more profitable markets that have set goals for selling certified products only. It is also foreseeable that, by increasing the expectations of consumers, retailers and restaurants, certification will lead to a gradual 'ratcheting up' (Cashore et al., 2007) of the overall performance of sustainability expectations and performance in the industry. Thus, the impact of certification could also extend to non-certified fisheries.

Empirical evidence has shown both evidence of the impact that certification can have on fisheries, as well as highlighting the limitations certification faces in creating global change. The Marine Stewardship Council (MSC), for instance, has expanded to include 275 certified fisheries in 36 countries with a total of 8.8 million metric tons of seafood caught annually (representing ca. 10\% of the annual global harvest; Agnew et al., 2013a; MSC, 2016). It has also demonstrated continued environmental and management improvements in those fisheries that are certified against its standards (Martin et al., 2012; MSC, 2015). However, the MSC has also faced criticisms over its bias towards large-scale over smallscale fisheries and operations, as well as its under-representation of developing country producers (Ponte, 2012; Gulbrandsen, 2009; Bush et al., 2013), despite the fact that developing countries account for $50 \%$ of the value of global seafood exports (Asche et al., 2015). It therefore appears that for certification to represent a truly global mechanism for change, it is important to move beyond consideration of the direct effects of certification, and to consider a wider set of institutional, economic and social conditions that influence its implementation and long-term impact.

The conditions that influence the successful uptake, as well as the factors that affect ecological and social impact, are key to understanding the overall legitimacy of certification as a private form of regulation. The uptake and impact also include wider process issues relating to assurance that certified catches are indeed sustainable (Froese and Proelss, 2012; Gutierrez et al., 2012; Agnew et al., 2013b), the effectiveness of objections procedures (Christian et al., 2013; Gutierrez and Agnew, 2013), the transparency, consistency and impartiality of assessment procedures (Miller and Bush, 2014) and the consistency of internal governance with the FAO 
Guidelines for Fisheries Certification (Sainsbury, 2008; Parkes et al., 2010). Other measures of legitimacy also extend to demonstrating the wider economic impacts of certification (Lallemand, 2016), and the degree to which these programs can validate their value proposition.

Against this background, the papers in this Special Issue address the wider conditions for the successful implementation and the overall impact of certification. Across 17 papers, authors explore in broad terms whether and how the limitations of certification can be overcome, and in doing so contribute to an evaluation of the future of certification. The papers cover fisheries in all continents (except Antarctica), from both developing and developed countries, and include both small-scale and industrial sectors. All but three papers are focused on the MSC certification program or MSC certified fisheries, with one on the FairTrade USA fishery standard, one on a Belgium National fishery standard (VALDUVIS) and one comparing several standards including MSC, Friend of the Sea and Seafood Watch. Six papers cover issues related to assessing attributes leading to successful certification, seven assess impacts of fisheries certification both at the fishery and broader level, and the final four cover other topics such as alternative uses and benchmarking of certification standards, and elements of their credibility and rigor. Perhaps most notably, half of the papers assess the implications of fisheries certification for developing countries, or fisheries within developing countries, despite their under-representation in major certification programs like the MSC. The following presents an overview of the papers in the Special Issue divided into the two key themes of uptake and impact, before outlining some of the main conclusions of the collection.

\section{Assessing conditions for successful certification}

In terms of the MSC standard, Performance Indicators (PIs) for a fishery are scored on a 0-100 scale. If a fishery achieves a score between 60 and 79 for any individual PI (conditional pass), it is required to develop an action plan to improve performance to achieve a score of 80 within the 5 years period of the certificate (MSC, 2014). Bellchambers et al. (2016a) investigate patterns in the condition types received by MSC certified fisheries to identify risk areas based on target species, fishing methods and geographic regions. The authors find that fisheries targeting crab/lobster, large pelagic finfish and flatfish, and fisheries operating in the UK/Europe and the NE Pacific regions, have more conditions related to the target species' stock status (MSC Principle 1). Ecosystem (MSC Principle 2) conditions were more frequently imposed on fisheries using demersal trawls or longlines. Concerning Governance/Management (MSC Principle 3), conditions have mainly been applied to shrimp and crab/lobster fisheries, fisheries in the NW Atlantic region and dredge fisheries. The authors suggest mitigation strategies for common high-risk areas, which have important implications particularly for small-scale and developing world fisheries that have limited resources and therefore need to minimize the number of conditions applied. These common risks areas could be used to provide more explicit guidance, which might desirably be incorporated in the MSC standard.

Catch shares have been documented as an effective rights-based management tools to improve fisheries' performance (Costello et al., 2016) and to prevent severe declines in fish catches (Costello et al., 2008; Essington et al., 2012). Parkes et al. (2010, 2016) analyze the effects of catch share management on the scores achieved by MSC certified fisheries. They evaluate differences in the assessment scores of certified fisheries managed with and without catch shares, and show that fisheries using this management tool had a higher probability of exceeding a threshold level (i.e., unconditional pass) for several PIs. Higher-scoring MSC certified fisheries have been about twice as likely to be managed with catch shares as without. However, these effects are also dependent on other fishery characteristics, some of which affected scores independently of whether or not the fishery was managed using catch shares. Following a similar methodological approach to Parkes et al. $(2010,2016)$ and Underwood et al. (2016) use Bayesian Belief Networks (BBNs) to also investigate how management interventions (e.g., catch shares) or fishery characteristics (e.g. gear type) affect the performance of a fishery using the MSC certification scores for more than 30 indicators. The authors conclude that BBNs are useful to (1) compare the probability of scoring highly on all three MSC Principles or indicators for fisheries with different characteristics and management strategies, (2) identify whether a fishery that scores highly on all three Principles is more likely to be managed using catch shares, and (3) identify the characteristics and indicators that are most associated with obtaining high scores across all three Principles. The methodological approach provides a robust framework for understanding how fishery characteristics and management interventions affect multiple aspects of fishery performance.

Although the MSC has shown a considerable increase in uptake by fisheries and markets, particularly in the developed world (MSC, 2015), there is considerable debate about whether MSC fisheries certification is a suitable option for fisheries in the developing world. Stratoudakis et al. (2016) review constraints to MSC certification in developing world fisheries, evaluate solutions and recommend actions to improve MSC uptake by these fisheries. To this end, an ad-hoc questionnaire survey was developed and distributed to a group of MSC stakeholders. Their main recommendations to the MSC include researching and benchmarking suitable data-limited assessment methods, systematizing and making readily available the successful management strategies of certified fisheries worldwide, and constructing specific fisheries capacity building for regional leaders in developing countries. The authors also argue that certification costs should be reviewed for smallscale fisheries and that a fund should be mobilized to support these fisheries, which should be channeled particularly to develop market opportunities, infrastructures and institutional capacities. Lastly, for fisheries that may never move towards certification, the MSC standard could be recognized and used as a fisheries best practice model for management and governance.

In a similar context, Pérez-Ramírez et al. (2016) assess which conditions facilitated the implementation of MSC certification in the 10 MSC-certified fisheries in Latin America and the Caribbean (LAC), which constitute only $4 \%$ of the total number of certified fisheries globally yet almost half of all developing world fisheries. The authors review the factors driving fishing industries in LAC to pursue MSC certification and assess the overall performance of these fisheries against the MSC standard. They show that MSC certification is suitable for large, multi-national enterprises with export-oriented markets and for small-scale fisheries with exclusive access rights harvesting high-value resources. Moreover, most LAC certified fisheries show high performance in terms of stock status, governance and management systems. Intrinsic weaknesses of LAC fisheries (e.g., limited information and instability in governance systems), high certification costs and extrinsic market conditions are identified as bottlenecks for the expansion of MSC certification in LAC. Development of domestic certified seafood markets, and changes in the MSC standard directed to promote greatly enhanced inclusiveness of small-scale fisheries with traditional management arrangements (e.g., more flexibility to accommodate local or regional conditions) are identified as important steps toward a more sustainable pathway in LAC.

While the MSC fisheries standard only focuses on environmental performance, the FairTrade USA fisheries certification program includes social and economic components. Bailey et al. (2016) explore the role of middlemen in the handline-caught yellowfin 
tuna from Molucca, Indonesia (the first Fair Trade USA certified fishery). Interviews with critical stakeholders (including fishers, middlemen, the local processor and those involved in Fair Trade implementation) were conducted and analyzed to evaluate how middlemen contribute to the assets and capabilities of fishers. The authors show that Fair Trade certification has facilitated a rapid reorganization of value chain structure in the fishery and has had an impact on fisher perceptions of the resource and the market. However, middlemen still control the full range of assets required to enable fishers to fulfill their value chain functions, suggesting that the fisher-middlemen dynamics should be considered as a critical component of the value chain structure and should therefore be explicitly considered within its standard. This is particularly important in developing countries where local middlemen often play a central role not only in trading fish, but also in providing fishers with access to capital, infrastructure and essential services.

\section{Impacts of fisheries certification}

The second key theme of the Special Issue relates to the impacts of fisheries certification. After the first tuna fishery was certified by the MSC in 2007, many others followed rapidly with 12 fisheries in both developed and developing countries currently certified, and 11 others in different stages of the certification process. Of these, the Parties to the Nauru Agreement (PNA) skipjack tuna fishery was certified in 2011. Harvesting almost 1.9 million metric tons of tuna, at a value of US\$3.9 billion, in 2013 (ca. $72 \%$ of the total tuna harvest by weight in the Western and Central Pacific Ocean), this purse seine fishery is a major player in this regional fishery and its associated ecosystem.

Two studies analyze the impacts of MSC certification for the PNA skipjack tuna operations at both the fishery and the value chain levels. Groeneveld and Quaas (2016) analyze the economic and biological effects of this certification by simulating a series of scenarios using bioeconomic models. The authors find that certification of the PNA unassociated-sets fishery is likely to enhance the stocks of both skipjack tuna and bigeye tuna (considered the most vulnerable tuna species in the region), while negatively affecting yellowfin tuna stocks due to its higher catch rates in unassociated fisheries. Through simulations, the authors argue that stock status could be improved, and that access fees could be increased provided measures are taken to change the catchability coefficient of the unassociated-sets fishery for yellowfin tuna. In practice, this would mean a change in targeting behavior by unassociated-sets purse seine fishers, for example by introducing catch quotas (through a TAC) for yellowfin tuna.

Adolf et al. (2016) analyze the effect of MSC certification on the capacity of States in repositioning themselves in the global tuna value chain, using the PNA skipjack fishery as a case study. In contrast to arguments that States have a limited capacity to steer sustainable production of transnational fishery resources (Allen et al., 2010), the authors highlight how PNA created the conditions for its small island member States to use MSC certification to expand their proprietary roles for tuna resources and to become global actors themselves through this public-private partnership. They argue that countries can use this market demand for MSC certified tuna to improve their position as both producers and intermediaries in the value chain, and therefore increase sovereign control over tuna resources while improving their capacity for domestic wealth generation.

While highly migratory tuna species have shown a recent rapid increase in certification and ecolabeling uptake due to high market demand, sedentary lobster fisheries were among the first to enter the MSC program. Specifically, the Western Australian rock lobster was the first to be certified globally in 2000, while Mexico's Baja
California provided the first certified fishery in a developing country in 2004. Both fisheries have been re-certified on several occasions and subjected to many improvement action plans (i.e., conditions).

In this context, Bellchambers et al. (2016b) discuss and compare the challenges and benefits associated with the certification process in both fisheries, highlighting a similarity in the conditions imposed to address weaknesses identified in the assessment process (which were mostly related to data deficiencies). These include a better understanding of target stock status, improving monitoring and reporting of bycatch and Endangered Threatened and Protected species (ETPs), improving the understanding of the potential impacts of fishing on the ecosystem, and implementing comprehensive research plans. Although ca. $20 \%$ of global wild production of lobster is currently MSC certified, the authors highlight the lack of evidence of a price premium for either Western Australian or Mexican Baja California lobster. In fact, the vast majority of the catches sold of both lobster species do not carry the MSC logo due to the additional cost associated with its use. Nonetheless, the authors argue that in these two cases, and undoubtedly in a number of other fisheries around the world where domestic or international market recognition of MSC is not high, the social and political benefits of certification far outweigh any economic advantage.

Theoretically, an ecolabel will create an economic incentive for sustainable fisheries, as differentiated demand facilitated by the ecolabel may result in a price premium paid by consumers for labeled products over unlabeled products. Several studies have found that price premiums of between $10 \%$ and $14 \%$ are being paid for salmon, haddock and/or Alaska pollock at the retailer level in the UK (Roheim et al., 2011; Asche et al., 2015; Sogn-Grundvåg et al., $2013,2014)$. Even without the use of the ecolabel, market players (e.g., retailers, restaurants) can drive demand for seafood from certified fisheries. Researchers are only beginning to assess whether price premiums or other economic benefits are transmitted down the value chain to the fishers' level (e.g., Pope, 2009; Blomquist et al., 2015; Wakamatsu, 2014). This issue is critically important since fishers and industry are the ones bearing the costs associated with the fishery changes required by certification conditions (e.g., changes in fishing gear, improved monitoring) and to the certification process itself (e.g., certification body fees, data preparation).

Stemle et al. (2016) examine the potential effect of MSC certification on dockside (ex-vessel) prices from three different fisheries: salmon and halibut in Alaska, and flathead flounder in Kyoto, Japan. Utilizing comparable, uncertified fisheries in British Columbia, Canada and Japan, and a difference-in-difference statistical model, the results are mixed. After certification, differences between exvessel prices for certified chum and pink salmon and flathead flounder relative to their uncertified counterparts increased appreciably, while the price difference between certified and uncertified sockeye salmon declined. However, no substantial effects were evident for chinook and coho salmon and halibut. While the data do not allow for a clear attribution of these changes in price patterns to MSC certification, this remains a plausible explanatory factor. In combination with the other studies of price premiums at the ex-vessel level published to date, results of these studies are ambiguous regarding the impact of fisheries certification globally, and show a continued need to analyze the returns of certification at the fishers' level more closely.

The South African hake fishery has been certified since 2004 and constitutes the only MSC certified fishery in continental Africa. It therefore provides a suitable case to highlight the impacts of MSC certification in an industrial fishery in the developing world. While several authors have highlighted the assessment and environmental improvements associated with this certification (e.g., $90 \%$ reduction in seabird mortality, see Butterworth 2016; Field et al., 2013), no analyses of its economic impact on the hake fish- 
ery have been conducted previously. In this issue, Lallemand et al. (2016) analyze data on global production and trade of whitefish, as well as information from industry, NGOs and MSC-specific data, to estimate the potential progressive loss of fishery value in case of shifting to a non-certified scenario. Specifically, the authors show that the Net Present Value (NPV) for all simulations over a 5-year period reflects a $37.6 \%$ reduction vis-à-vis the status quo (i.e., certification). Furthermore, estimates of potential job losses in the absence of MSC certification range from around 5000-12000. The recent history of hake markets dynamics around the world and the role played by MSC certification in creating new opportunities in export markets have helped to sustain the value of the South African hake fishery despite the economic crisis in its original markets (i.e., Southern Europe) around 2008. This study shows that retaining MSC-certification is critical for the fishery to maintain its value and increase resilience to market shocks.

Butterworth (2016) provides a further perspective on how the certification process has affected South African fisheries at a broader level. In particular, the information-intensive, sciencebased MSC certification has enhanced government and industry attention to scientific recommendations. Furthermore, a common industry ethos around sustainability has emerged. In addition to these positive impacts, however, Butterworth (2016) also highlights some negatives: (1) the third-party nature of the MSC assessment process precludes collaboration between the scientific working group responsible of making management recommendations and the certification team responsible for the certification decision; this lack of early engagement has created inefficiencies in both the management and the certification processes; (2) given that many of the MSC requirements are a responsibility of the governmental agencies, making industry accountable for failures regarding these management elements (i.e., lack of government resources to conduct scientific surveys)renders accessing or retaining certification challenging; and (3) although some stakeholders, particularly NGOs, are arguing for "raising the bar" in the certification requirements, such more stringent performance requirements will serve to discourage underperforming fisheries from attempting the necessary changes to achieve certification. The author argues that as a result, the MSC process may achieve no more than marginal improvements in the performance of the top $10 \%$ of world's fisheries that are best managed.

On the other hand, Pristupa et al. (2016) discuss how the bilateral cooperation between Norway and Russia in successfully managing the Russian Barents Sea fisheries has not precluded the emergence of MSC certification. Their study concludes that the MSC has served primarily to provide a supplementary commercial advantage for Russian Barents Sea fisheries by ensuring access to the world market of sustainable fish and potentially providing a premium price. Specifically, as happened in the South Africa hake fishery (Butterworth, 2016) the certification mechanism urged companies to prioritize attention to ecosystem-related issues such as bycatch, discards and the negative effects of some bottom trawling through encouraging cooperation between fishing companies, NGOs and research institutions. However, the authors also argue that certification has contributed indirectly to a growing divide between larger-scale, internationally oriented, distant-water fishing companies and the smaller-scale coastal fisheries dependent on State support to implement effective management.

\section{Internal procedures and alternative uses of certification standards}

In a third party certification scheme, certification decisions can be challenged through a complaints process. In fact, FAO's Guidelines for Ecolabelling (FAO, 2005) require an independent, fair and transparent mechanism for objections to final determinations on sustainability as part of the certification process. In this respect, in 1999 the MSC introduced a specific Objection Procedure to deal with complaints and increase the organization's credibility. Notwithstanding this, several authors have debated whether the nature of this Procedure is appropriate to fulfill its objectives and whether it actually results in more impartial and better assessments (Christian et al., 2013; Gutierrez and Agnew, 2013). Brown et al. (2016) add to this debate by examining the origin and evolution of the MSC Objection Procedure. Although the rate of Objections has remained stable since 2006, recent trends suggest an increase in settlements through consultation and stakeholder dialogues without involvement of an independent legal adjudicator. Although only one fishery has failed certification due to an objection, the authors show that fishery improvements through changes in scores and new and modified action plans for improvements benefited the certification process by increasing credibility, accountability and fairness, and ultimately by broadening the impacts of certification.

Ecosystem-based fisheries management (EBFM) has been proposed as a holistic approach for managing fisheries (Pikitch et al., 2004). Although EBFM is a widely accepted concept, its operationalization remains challenging. Hazen et al. (2016) evaluate and compare four market-based frameworks (MSC, Friend of the Sea, Seafood Watch Program and FAO Guidelines for Ecolabeling) to assess fishery sustainability criteria and consider their potential applicability to fisheries management and governance. They also assess the alignment between the indicators used in these frameworks and the goals and requirements of the U.S. Marine Life Management Act (MLMA) implemented for fisheries management in California's coastal waters (Ruckelshaus et al., 2008). The authors find considerable overlap between the biophysical sustainability criteria assessed by these indicators and the requirements of the MLMA, revealing that these indicators align well with practical management needs, so that these sustainability indicators could be applied more broadly to assess progress towards EBFM goals. The authors also suggest the operationalization of a refined suite of indicators via decision trees or questionnaires for fishery managers to assess how well they are meeting EBFM objectives.

While transnational certification programs attract wider visibility and contribute to shape global seafood markets, national schemes are more adapted to the local context, therefore often getting more buy-in from local stakeholders (Kvalvik et al., 2014). Kinds et al. (2016) propose an indicator-based sustainability assessment tool intended to provide incentives for fishers to adopt more sustainable fishing practices in Belgium. An Integrated Sustainability Assessment was used as a framework to develop the tool and to initiate the transition towards sustainability in Belgian fisheries. To this end, indicator scores were calculated using electronic logbooks and then aggregated to the fishing trip level. Stakeholders played a key role in the development of the tool, enhancing the support of the fishing sector and assuring the relevance of the indicators and the users' understanding of the approach. The authors suggest that the tool developed offers a cost-effective alternative to the certification schemes that already exist, and could be suitable for monitoring the progress of Belgian fisheries towards sustainability.

As highlighted by this Special Issue, well designed and effectively implemented certification schemes may incentivize improvements by providing market recognition. Therefore seafood certification schemes for both wild harvest fisheries and aquaculture are proliferating. Such a myriad of certification schemes and standards, including seafood guides, may cause confusion for industry, retailers and even consumers on what the scope of an ecolabel is as well as the rigor associated with its standard and certification processes (Roheim, 2009; Parkes et al., 2010; Hilborn et al., 2015). In an attempt to shed some light on this issue, Tlusty et al. 
(2016) develop a breath-depth (B-D) analytical tool for standards comparison using aquaculture schemes as case studies. The authors find that global schemes (e.g., the Aquaculture Stewardship Council) are of greater breadth and depth than national schemes (e.g., Indonesia, Vietnam and Thailand shrimp aquaculture schemes). The B-D analysis provides a relatively simple means to assess the rigor of multiple certification standards by using a broad baseline set of factors, as well as to better understand similarities and differences between standards.

\section{Conclusions}

Overall, the contributions in this volume clearly demonstrate that fisheries certification and ecolabelling has grown as a market-based approach to incentivize best practices and recognize sustainable management. However, they also highlight some of the limitations or barriers that some fisheries, particularly in developing countries, may have to access these programs. Specifically, costs of certification and those associated with improvements needed to achieve or maintain the certificates, as well as data and technical limitations to comply with the ecolabel's standards, are mentioned as the main bottlenecks for these fisheries.

Whether direct or indirect, the impacts of fisheries certification are evident in this Special Issue. Positive effects are most often related to the objectives for which certification was pursued, including retaining markets or access new ones, price premiums and/or additional pressure to achieve or maintain sustainable practices. More indirect impacts of certification encompass increased data collection and information, enhanced stakeholder cooperation and increased sustainability awareness and consciousness across the value chain. However, the studies included in this Special Issue also highlight some more indirect negative impacts, such as high-bar requirements discouraging the fisheries most in need of improvement from attempting certification, as well as a greater divide between larger-scale, internationally oriented fishing companies and smaller-scale coastal producers dependent on State support to implement effective management. A further problem is penalizing fishing industries in circumstances of governments failing in areas for which they carry responsibility. If these conditions for successful uptake can be addressed, and the wider impacts of certification better understood by key fishery actors, then the overall legitimacy of certification is likely to be sustained.

In summary, the major positive impact certification and ecolabelling has had on improving fisheries sustainability must be acknowledged. In fact, it has probably had a greater effect in this regard than any other non-State fisheries management initiative over the past decade. Nonetheless, what the results also show is that certification does not exist in isolation from the State, nor other fisheries governance tools. In this way, the further expansion of certification as a mechanism for change cannot be understood only in the narrow terms of impacts on fish stocks. Instead, it also needs to be understood in terms of how it creates secondary economic and governance impacts that not only maintain incentives for engaging in fisheries improvement, but also lead to structural changes to fisheries policy and management. These in turn ultimately extend to those fisheries that are not certified, and for various reasons are never likely to be.

\section{References}

Adolf, S., Bush, S.R., Vellema, S., 2016. Reinserting state agency in global value chains: the case of MSC certified skipjack tuna. Fish. Res. 182, 79-87.

Agnew, D.J., Gutierrez, N.L., Stern-Pirlot, A., Hoggarth, D.D., 2013a. The MSC experience: developing an operational certification standard and a market incentive to improve fishery sustainability. ICES J. Mar. Sci. 71 (2), 216-225.
Agnew, D.J., Gutierrez, N.L., Stern-Pirlot, A., Smith, A.D.M., Zimmermann, C. Sainsbury, S., 2013b. Rebuttal to Froese and Proelss "Evaluation and legal assessment of certified seafood". Mar. Policy 38, 551-553.

Allen, R., Joseph, J., Squires, D. (Eds.), 2010. Front Matter, in Conservation and Management of Transnational Tuna Fisheries. Wiley-Blackwell, Oxford, UK.

Asche, F., Larsen, T.A., Smith, M.D., Sogn-Grundvåg, G., Young, J.A., 2015. Pricing of eco-labels with retailer heterogeneity. Food Policy 53, 82-93.

Bailey, M., Simon Bush, S., Oosterveer, P., Larastiti, L., 2016. Fishers, fair trade, and finding middle ground. Fish. Res. 182, 59-68.

Bellchambers, L., Fisher, E.A., Harry, A.V., Travaille, K.L., 2016a. Identifying and mitigating potential risks for Marine Stewardship Council assessment and certification. Fish. Res. 182, 7-17.

Bellchambers, L.M., Phillips, B.F., Pérez-Ramírez, M., 2016b. From certification to recertification the benefits and challenges of the Marine Stewardship Council (MSC): a case study using lobsters. Fish. Res. 182, 88-97.

Blomquist, J., Bartolino, V., Waldo, S., 2015. Price premiums for providing eco-labelled seafood: evidence from MSC-certified Cod in Sweden. J. Agr. Econ. 66 (3), 690-704

Brown, S., Agnew, D.J., Martin, W., 2016. On the road to fisheries certification: the value of the objections procedure in achieving the MSC sustainability standard. Fish. Res. 182, 136-148.

Bush, S.R., Toonen, H., Oosterveer, P., Mol, A.P.J., 2013. The 'devils triangle' of MSC certification balancing credibility, accessibility and continuous improvement. Mar. Policy 37, 288-293.

Butterworth, D.S., 2016. The South African experience with MSC certification: a perspective. Fish. Res. 182, 124-127.

Cashore, B., Auld, G., Bernstein, S., McDermott, C., 2007. Can non-state governance 'ratchet up' global environmental standards? Lessons from the forest sector. Rev. Eur. Community Int. Environ. Law 16 (2), 158-172.

Christian, C., Ainley, D., Bailey, M., Dayton, P., Hocevar, J., et al., 2013. A review of formal objections to Marine Stewardship Council fisheries certifications. Biol. Conserv. 161, 10-17.

Costello, C., Gaines, S.D., Lynham, J., 2008. Can catch shares prevent fisheries collapse? Science 321, 1678-1681.

Costello, C., Ovando, D., Clavelle, T., Kent Strauss, C., et al., 2016. Global fishery prospects under contrasting management regimes. Proc. Natl. Acad. Sci., http://dx.doi.org/10.1073/pnas.1520420113 (Early view March 28, 2016).

Essington, T.E., Melnychuk, M.C., Branch, T.A., Heppell, S.S., et al., 2012. Catch shares, fisheries, and ecological stewardship: a comparative analysis of resource responses to a rights-based policy instrument. Conserv. Lett. 5 (3), $186-195$.

Field, J.G., Attwood, C.G., Jarre, A., Sink, K., Atkinson, L.J., Petersen, S., 2013. Cooperation between scientists, NGOs and industry in support of sustainable fisheries: the South African hake Merluccius spp. trawl fishery experience. J. Fish Biol. 83 (4), 1019-1034.

Food Agricultural Organization of the United Nations, 2005. Guidelines for the Ecolabelling of Fish and Fishery Products from Marine Capture Fisheries. FAO, Rome.

Food, Agricultural Organization of the United Nations, 2014. The State of World Fisheries and Aquaculture 2014. FAO, Rome.

Froese, R., Proelss, A., 2012. Evaluation and legal assessment of certified seafood. Mar. Policy 36, 1284-1289.

Groeneveld, R.A., Quaas, M.F., 2016. Promoting selective fisheries through certification? An analysis of the PNA unassociated-sets purse seine fishery. Fish. Res. 182, 69-78.

Gulbrandsen, L.H., 2009. The emergence and effectiveness of the Marine Stewardship Council. Mar. Policy 33, 654-660.

Gutierrez, N.L., Agnew, D.J., 2013. MSC objection process improves fishery certification assessments: a comment to Christian et al. (2013). Biol. Conserv. $165,212-213$

Gutierrez, N.L., Hilborn, R., Defeo, O., 2011. Leadership, social capital and incentives promote successful fisheries. Nature 470, 386-389.

Gutierrez, N.L., Valencia, S.R., Branch, T.A., Agnew, D.J., et al., 2012. Eco-label conveys reliable information on fish stock health to seafood consumers. PLoS One 7 (8), e43765.

Hazen, L., Le Cornu, E., Zerbe, A., Martone, R., Erickson, A.L., Crowder, L.B., 2016. Translating sustainable seafood frameworks to assess the implementation of ecosystem-based fisheries management. Fish. Res. 182, 149-157.

Kinds, A., Sys, K., Schotte, L., Mondelaers, K., Polet, H., 2016. VALDUVIS: an innovative approach to assess the sustainability of fishing activities. Fish. Res. $182,158-171$

Kvalvik, I., Noestvold, B.H., Young, J.A., 2014. National or supranational fisheries sustainability certification schemes?: a critical analysis of Norwegian and Icelandic responses. Mar. Policy 46, 137-142.

Lallemand, P., Bergh, M., Hansen, M., Purves, M., 2016. Estimating the economic benefits of MSC certification for the South African hake trawl fishery. Fish. Res. $182,98-115$.

Martin, S., Cambridge, T., Grieve, C., Nimmo, F., Agnew, D.A., 2012. Environmental impacts of the Marine Stewardship Council certification scheme. Rev. Fish. Sci. 20, 61-69.

Miller, A.M., Bush, S.R., 2014. Authority without credibility? Competition and conflict between ecolabels in tuna fisheries. J. Clean. Prod. 107, $137-145$.

MSC, 2014. MSC Fisheries Certification Requirements and Guidance. Marine Stewardship Council, London.

MSC, 2015. Global Impacts Report 2015. Marine Stewardship Council, London. 
MSC., 2016. Marine Stewardship Council website.www.msc.org. (accessed 04.04.16.).

Parkes, G., Young, J.A., Walmsley, S.F., Abel, R., et al., 2010. Behind the Signs-a global review of fish sustainability information schemes. Rev. Fish. Sci. 18 344-356.

Parkes, G., Swasey, J.H., Underwood, F.M., Fitzgerald, T.P., Strauss, K., Agnew, D.J., 2016. The effects of catch share management on MSC certification scores. Fish. Res. 182, 18-27.

Pikitch, E.K., Santora, C., Babcock, E.A., Bakun, A., Bonfil, et al., 2004. Ecosystem-based fisheries management. Science 205, 346-347.

Pérez-Ramírez, M., Castrejón, M., Gutierrez, N.L., Defeo, O., 2016. The Marine Stewardship Council certification in Latin America and the Caribbean: a review of experiences, potentials and pitfalls. Fish. Res. 182, 50-58.

Pristupa, A.O., Lamers, M., Amelung, B., 2016. Private informational governance in Post-Soviet waters: implications of the Marine Stewardship Council certification in the Russian Barents Sea region. Fish. Res. 182, 128-135.

Ponte, S., 2012. The marine stewardship council (MSC) and the making of a market for 'Sustainable fish'. J. Agrar. Change 12, 300-315.

Pope, F., 2009. MSC Scheme Proves a Boon for Fishermen Despite Fear Over Stocks. Times (UK) (September 30, 2009).

Hilborn, R., Fulton, E.A., Green, B.S., Hartmann, K., Tracey, S.R., Watson, R.A., 2015. When is a fishery sustainable? Can. J. Fish. Aquat. Sci. 72, 1433-1441.

Roheim, C.A., 2009. An evaluation of sustainable seafood guides: implications for environmental groups and the seafood industry. Mar. Res. Econ. 24 (3), 301-310.

Roheim, C.A., Asche, F., Insignares, J., 2011. The elusive price premium for ecolabelled products: evidence from seafood in the UK market. J. Agric. Econ. 62 (3), 655-668.

Ruckelshaus, M., Klinger, T., Knowlton, N., DeMaster, D.P., 2008. Marine ecosystem-based management in practice: scientific and governance challenges. Bioscience 58, 53-63.

Sainsbury, K., 2008. Review of Guidelines for Ecolabelling of Fish and Products from Capture Fisheries, and Recommended Minimum Substantive Requirements. Food and Agriculture Organization of the United Nations, FAO, Rome (accessed 30.03.16.).

Sogn-Grundvåg, G., Larsen, T.A., Young, J.A., 2013. The value of line-caught and other attributes: an exploration of price premiums for chilled fish in UK supermarkets. Mar. Policy 38, 41-44.

Sogn-Grundvåg, G., Larsen, T.A., Young, J.A., 2014. Product differentiation with credence attributes and private labels: the case of whitefish in UK supermarkets. J. Agric. Econ. 65 (2), 368-382.

Stemle, A., Uchida, H., Roheim, C.A., 2016. Have dockside prices improved after MSC certification? Analysis of multiple fisheries. Fish. Res. 182, 116-123.

Stratoudakis, Y., McConney, P., Duncan, J., Ghofar, A., Gitonga, N., Mohamed, K.S., Samoilys, M., Symington, K., Bourillon, L., 2016. Fisheries certification in the developing world: locks and keys or square pegs in round holes? Fish. Res. 182, 39-49.
Tlusty, M.F., Thompson, M., Tausig, H., 2016. Statistical tools to assess the breadth and depth of shrimp aquaculture certification schemes. Fish. Res. 182, $172-176$.

Underwood, F.M., Parkes, G., Swaseyc, J.H., 2016. Building Bayesian Belief Networks to investigate how fishery performance responds to management interventions. Fish. Res. 182, 28-38.

Wakamatsu, H., 2014. The impact of MSC certification on a japanese certified fishery. Mar. Resour. Econ. 29 (1), 55-67.

Worm, B., Hilborn, R., Baum, J.K., Branch, T.A., et al., 2009. Rebuilding global fisheries. Science 325, 578-585.

Nicolas L. Gutierrez* Fisheries and Aquaculture Department, Food and Agricultural Organization of the United Nations, 00153, Rome Italy

Omar Defeo

UNDECIMAR, Faculty of Sciences, Iguá 4225, 11400 Montevideo, Uruguay

Simon R. Bush

Environmental Policy Group, Wageningen University, The Netherlands

Doug S. Butterworth Marine Resource Assessment and Management Group (MARAM), Department of Mathematics and Applied Mathematics, University of Cape Town, Rondebosch 7701, South Africa

Cathy A. Roheim Department of Agricultural Economics and Rural Sociology, University of Idaho, Moscow ID 83843, USA

Andre E. Punt School of Aquatic and Fishery Sciences, 1122 NE Boat St., Seattle, WA 98105, USA

* Corresponding author. Available online 24 May 2016 